\title{
Contents, Vol 35, 1995
}

Founded 1897 as 'Monatsschrift fur Psychiatrie und Neurologie', continued 1957-1967 as 'Psychiatria et Neurologia'

Founders: C. Wernicke and Th. Ziehen.

Successors: K. Bonhoeffer (1912-1938), J. Klaesi (1939-1967), E. Grunthal (1953-1967),

H.E. Kaeser (1968-1993)

\section{Editor-in-Chief}

J. Bogousslavsky, Lausanne

\section{Associate Editors}

J.G. Hildebrand, Brussels L.R. Caplan, Boston, Mass.

\section{Associate Editor (Neuroscience)}

M. Fisher, Worcester, Mass.

\section{Assistant Editor}

Th. Kuntzer, Lausanne 


\section{Editorial Board}

Z. Argov, Jerusalem

Th.D. Bird, Seattle, Wash.

W.T. Blume, London, Ont

Chr. Confavreux, Lyon

A.R. Damasio, Iowa City, Iowa

J. Dichgans, Tubingen

S. Di Donato, Milan

A.G. Engel, Rochester, Minn.

J.H. Growdon, Boston, Mass.

S. Harel, Tel Aviv

C. Hess, Berne

L. Kappos, Basel

J. Kimura, Kyoto

A.D. Korczyn, Tel Aviv

P. Krauseneck, Bamberg

Th. Landis, Geneva

C. Loeb, Genova

E. Lugaresi, Bologna

P. Magistretti, Lausanne

F. Mauguiere, Lyon

O. Meienberg, Basel 
F.G.A. van der Meche, Rotterdam H.W. Moser, Baltimore, Md.

D.Neary, Manchester

J. Newsom-Davis, Oxford J. Olesen, Copenhagen Ch. Pierrot-Deseilligny, Paris H. Reichmann, Wurzburg W.A. Rocca, Rochester, Minn. A.B. Safran, Geneva E. Satoyoshi, Tokyo

P. Scheltens, Amsterdam S.D. Shorvon, London C.J.M. Sindic, Bruxelles P.K. Thomas, London N. de Tribolet, Lausanne A. Valavanis, Zurich F. Vassella, Berne

J.P. Vonsattel, Boston, Mass. J.H.J. Wokke, Utrecht A. Yamadori, Sendai D.S. Zee, Baltimore, Md.

\section{KARGE}

Medical and Scientific Publishers Basel $\bullet$ Freiburg $\bullet$ Paris $\bullet$ London New York $\bullet$ New Delhi $\boldsymbol{\bullet}$ Bangkok Singapore $\bullet$ Tokyo $\bullet$ Sydney 
The authors and the publisher have exerted every effort to ensure that drug selection and dosage set forth in this text are in accord with current recommendations and practice at the time of publication. However, in view of ongoing research, changes in government regulations, and the constant flow of information relating to drug therapy and drug reactions, the reader is urged to check the package insert for each drug for any change in indications and dosage and for added warnings and precautions. This is particularly important when the recommended agent is a new and/or infrequently employed drug. 
Contents Vol. 35,1995

No. 1

Message from the Editor

Bogousslavsky, J.

\section{Emerging Therapies in Neurology}

Potentially Effective Therapies for Acute Ischemic Stroke 3 Fisher, M.

Clinical Review

Molecular Genetics of Alzheimer Disease: Identification of Genes and Gene Mutations Van Broeckhoven, C.L.

\section{Original Papers}

The Pattern of Motor Deficits in Relation to the Site of Stroke 20 Lesions

Kunesch, E.; Binkofski, F.; Steinmetz, H.; Freund, H.-

Hyperkinetic Motor Behaviors Contralateral to Hemiplegia in 27 Acute Stroke

Ghika, J.; Bogousslavsky, J.; van Melle, G; Regli, F.

Evaluation of Fifth Nerve Dysfunction in 136 Patients with Middle and Posterior Cranial Fossae Tumors

Puca, A.; Meglio, M.; Vari, R.; Tamburrini, G.; Tancredi, A

History of Brain and Epidural Metastases from Breast Cancer 38 in Relation with the Disease Evolution outside the Central Nervous System Dethy, S.; Piccart, M.J.; Paesmans, M.; van Houtte, P.; Klastersky, J. Treatment of Hemifacial Spasm with Botulinum Toxin. Value 43 of Preinjection Electromyography Abnormalities for Predicting Postinjection Lower Facial Paresis Angibaud, G.; Moreau, M.S.; Rascol, O.; Clanet, M.

Parkinsonism in Patients with Lacunar Infarcts of the Basal

Ganglia

Reider-Groswasser, I.; Bornstein, N.M.; Korczyn, A.D. 
Short Reports

Corticobasal Degeneration: Neuropsychological Assessment $\quad 50$

and Dopamine D2 Receptor SPECT Analysis Frisoni, G.B.; Pizzolato, G.; Zanetti, O.; Bianchetti, A.; Chierichetti, F.; Trabucchi, M.

Nephrolithiasis and Nephrocalcinosis in Cerebrotendinous 55

Xanthomatosis: Report of Three Siblings Chang, W.-N.; Cheng, Y.-F

Utilization Behavior after Right Thalamic Infarction

Hashimoto, R.; Yoshida, M.; Tanaka, Y

\section{Letter to the Editor}

A Case of Cortical Tremor as a Variant of Cortical Reflex

Myoclonus

Oguni, E.; Hayashi, A.; İshii, A.; Mizusawa, H.; Shoji, S

No. 2 
Treatment of Amyotrophic Lateral Sclerosis Using a Gene

Therapy Approach Aebischer, P.; Kato, A.C.

\section{Clinical Review}

Familial Young-Adult-Onset Arteriosclerotic Leukoencepha- 69 lopathy with Alopecia and Lumbago without Arterial Hypertension Fukutake, T.; Hirayama, K.

\section{Original Papers}

Spatial and Perceptual Impairment Related to Cortical Cere- 80 bral Blood Flow and EEG in Deep White Matter Infarcts of the Right Hemisphere Bradvik, B.; Sonesson, B.; Ryding E.; Rosen, I. Evaluation of Influential Factors of Cognititve Impairments in 86

Idiopathic Parkinson's Disease

Fukui, T.; Sato, Y.; Ichikawa, H.; Takeuchi, T.; Sugita, K.;

Tsukagoshi, $\mathrm{H}$

Neurophysiological and Urodynamic Examinations in the 93

Functional Assessment of the Spinal Cord below the Injury Site Zanette, G.; Righetti, C; Manganotti, P.; Polo, A.; Tinazzi, M.; Fiaschi, A.; Tosi, L.

Grades of Exophthalmos and Thyrotropin-Binding Inhibitory 99 Immunoglobulin in Patients with Myasthenia Gravis Okada, S.; Saito, E.; Ogawa, T.; Sadamoto, K.; Kinoshita, M.

Motor Neuron Disease and Monoclonal Gammopathy

104

Lavrnic, D.; Vidakovic, A.; Miletic, V.; Trikic, R.; Marinkovic, Z.; Rakocevic, V.; Nikolic, J.; Wirguin, I.; Sadiq, S.A.; Apostolski, S.

Endothelial Cell Damage in Sarcoidosis and Neurosarcoidosis: 108 Autoantibodies to Endothelial Cells Tsukada, N.; Yanagisawa, N.; Mochizuki, I.

Seronegative Chronic Relapsing Neuroborreliosis

113

Lawrence, C; Lipton, R.B.; Lowy, F.D.; Coyle, P.K

\section{Issues in Neurologic Practice}

Handling of Single Brain Metastasis

Section Editor: Caplan, L.R. 
Gasecki, A.P.; Kwieciriski, H.

\section{Original Papers}

Functional Magnetic Resonance Imaging at $1.5 \mathrm{~T}$ during Sen- 131

sorimotor and Cognitive Task

Sabbah, P.; Simond, G.; Levrier, O.; Habib, M.; Trabaud, V.;

Murayama, N.; Mazoyer, B.M.; Briant, J.F.; Raybaud, Ch.; Salamon, G.

Evaluation of Outcome of Delayed Neurologic Sequelae after 137 Carbon Monoxide Poisoning by Technetium-99m Hexamethyl-propylene Amine Oxime Brain Single Photon Emission Computed Tomography Choi, I.S.; Kim, S.K.; Lee, S.S.; Choi, Y.C.

Methylprednisolone Infusion during Acute Exacerbation of 143

MS: Plasma and CSF Concentrations

Defer, G.-L.; Barre, J.; Ledudal, P.; Tillement, J.-P.; Degos, J.-D.

Segmental Hyperhidrosis in Two Siblings with Chiari Type I 149

Malformation

Stovner, L.J.; Sjaastad, O.

Single Photon Emission Computed Tomography Using

N-Isopropyl- $/>\left[{ }^{[23} I\right]$ Iodoamphetamine in Spinocerebellar

Degeneratio

Ohkoshi, N.; İshii, A.; Shoji, S.

Cerebellar Herniation in Syringomyelia: Relation between

Tonsillar Herniation and the Dimensions of the Syrinx and the Remaining Spinal Cord. A Quantitative MRI Study Masur, H.; Oberwittler, C; Reuther, G.; Heyen, P.

The 3243 MELAS Mutation in a Pedigree with MERRF

Folgera, T.; Torbergsen, T.; 0ian, P.

\section{Letters to the Edito}

Late-Onset Rasmussen's Syndrome with First Seizure during 172

Pregnancy

Larner, A.J.; Smith, S.J.M.; Duncan, J.S.; Howard, R.S.

Cerebral Infarction Associated with 3,4-Methylenedioxy-

methamphetamine ('Ecstasy') Abuse

Hanyu, S.; Ikeguchi, K.; Imai, H.; Imai, N.; Yoshida, M.

Idiopathic Hypereosinophilic Syndrome with a Radiologic

Pattern of Central Pontine Myelinolysis

Menage, P.; de Toffol, B.; Saudeau, D.; Watier, H.; Bardos, P.;

Autret, A.

Multimodality Evoked Potentials and EEG in a Case of Cherry 175 Red Spot-Myoclonus Syndrome and Alpha-Neuraminidase Deficiency (Sialidosis Type 1) Louboutin, J.P.; Nogues, B.; Caillaud, G; Elie, B. 
Patient with Rheumatoid Arthritis

Zappia, M.; Valentino, P.; Bono, F.; Vita, G.; Aguglia, U.; Messina, C; Quattrone, A

Transient Cognitive Impairment due to Glioblastoma

Morreale, A.; Gallassi, R.; Lugaresi, E.; Tassinnari, C.A.

Isolated Acute Urinary Retention in Herpes Simplex Infection: 181 Selective Parasympathetic Spinal Involvement? Bartolomei, F.; Azulay, J.P.; Serratrice, G.

Mitochondrial Changes in Steroid Myopathy with Respiratory 182 Failure and Rapid Fatal Course: Report of a Case Malandrini, A.; Scarpini, C; Fabrizi, G.M.; Manneschi, L.; Rosi, R.; Parrotta, E.; Guazzi, G.C

Subclavian Steal Syndrome in Chronic Aortic Dissection

Meincke, U.; Mull, M.; Wendt, G.; Isensee, Ch.

Announcement

No. 4

\section{Editorial}

Dementia due to Lacunar Infarctions: A Misnomer or a Clini- 187 cal Entity? Loeb, C.

\section{Original Papers}

Double-Blind, Placebo-Controlled, Randomized, Crossover 193 Trial of High-Dose Methylprednisolone in Patients with Chronic Progressive Form of Multiple Sclerosis Cazzato, G.; Mesiano, T.; Antonello, R.; Monti, F.; Carraro, N.; Torre, P.; Bosco, A.; Cargnelutti, D.

Mitochondrial Encephalomyopathies: CT and MRII Findings 199

and Correlations with Clinical Features

Huang, C.-C; Wai, Y.-Y.; Chu, N.-S.; Liou, C.-W.; Pang, C.-Y.

Shih, K.-D.; Wei, Y.-H.

Myotonia Congenita: Quantitation of Different Aspects of

Motor Performance

Effect of Collateral Flow Patterns on Outcome of Carotid Occlusion

Hedera, P.; Bujdakova, J.; Traubner, P.

Long-Term Therapy of Essential Tremor with Flunarizine

Biary, N.; Al Deeb, S.M.; Bahou, Y.

Short-Latency Somatosensory Evoked Potentials following

220

Median Nerve Stimulation in Four Patients with Medial Medullary Infarction Hashimoto, T.; Miyasaka, M.; Yanagisawa, N.

Alterations in Chromatic Contour Perception in de novo

226

Parkinsonian Patients

Buttner, Th; Kuhn, W ; Przuntek, H. 


\section{Short Report}

Divergence of Central Nervous System Involvement in 2 Ital- 230 ian Sisters with Congenital Muscular Dystrophy: A Clinical

and Neuroradiological Follow-Up

Trevisan, C.P.; Martinello, F.; Ferruzza, E.; Angelini, C.

\section{Letters to the Edito}

Respiratory Failure Associated with Hydroxychloroquine Neuromyopathy

Primary CNS Lymphoma in Association with IgM Kappa Paraproteinaemia and Peripheral Polyneuropathy: A Case Report

Blindness in Patients with Cryptococcal Meningitis and AIDS 239

Aseptic Meningitis: An Unusual Presentation of Multiple

Sclerosis

Peduncular Hallucinosis as the First Manifestation of Multiple 241 Sclerosis

Electrical Stimulation of the Cerebellum Normally Suppresses 243 Motor Cortical Excitability in a Patient with Ataxia due to a Lesion of the Middle Cerebellar Peduncle

Transient Hemineglect Syndrome

Cerebral Thromboangiitis obliterans: Clinical and MRI Find- 246 ings in a Case

No. 5

\section{Editorial}

High-Intensity Transient Signals: Evolution or Revolution in 249 Understanding Cerebral Embolism? Hennerici, M.

\section{Original Papers}

Remote Cortical Dysfunction as a Possible Cause of Subcorti- 254 cal Neglect? A Regional Cerebral Blood Flow Study Hublet, C; Demeurisse, G.; Paternot, J.; Colson, C.; Capon, A.

Patients with Low Stump Pressure and Possible Pressure Fall 259 in the Middle Cerebral Artery during Carotid Surgery May Be Identified Preoperatively by Transcranial Doppler Kjallman, L.; Blomstrand, C; Holm, J.; Lundh, T.; Volkmann, R.

Comparison of Subcutaneous Sumatriptan with Usual Acute 264

Treatments for Migraine

Boureau, F.; Chazot, G.; Emile, J.; Bertịn, L.; d’Allens, H.

Lymphocytapheresis in Combination with Immunosuppressive 270 Drugs for Refractory Myasthenia gravis: Two-Color Flow Cytometric Analysis of Changes in Peripheral Blood Lymphocyte Subsets Furutama, D.; Nakajima, H.; Shinoda, K.; Makino, S.; Ohsawa, N.

Is Haemodynamical Compromise a Specific Cause of Border 276 Zone Brain Infarcts following Cardiac Surgery? Hupperts, R.; Wetzelaer, W.; Heuts-van Raak, L.; Lodder, J.

Gonadal Dysfunction in Mitochondrial Encephalomyopathies 281 Chen, C.-M; Huang, C.-C.

Autonomic Neuropathy in Chronic Alcoholism: Evaluation of 287 Cardiovascular, Pupillary and Sympathetic Skin Responses Miralles, R.; Espadaler, J.M.; Navarro, X.; Rubies-Prat, J.

\section{Issues in Neurologic Practice}

How Should Clinicians Choose Treatment for Preventing

293

Stroke when Therapeutic Trials Are Not Available to Guide the Situation? Caplan, L.R.

Announcement

No. 6

\section{Issues in Neurologic Practice}

Management of Cervical Radiculopathy

\section{Original Papers}

'Atypical'Tremor

Henderson, J.M.; Einstein, R.; Jackson, D.M.; Byth, K.; Morris, J.G.M.

Fractal Description of Cerebral Cortical Patterns in Frontal 327 Lobe Epilepsy

Cook, M.J.; Free, S.L.; Manford, M.R.A.; Fish, D.R.; Shorvon, S.D.; Stevens, J.M

Chronic Relapsing Neuropathy Associated with Castleman’s 336 Disease (Angiofollicular Lymph Node Hyperplasia) Vingerhoets, F.; Kuntzer, T.; Delacretaz, F.; Steck, A.J.; Knecht, H.; Bogousslavsky, J.; Meier, C; Regli, 
Proglumide, a Cholecystokinin Receptor Antagonist, Reduces 344 Neuroleptic Action in Huntington's Chorea

Piolti, R.; Appollonio, I.; Perego, M.; Pozzi, C; Rovati, L.;

Ferrarese, C; Frattola, L.

POEMS Syndrome in Chinese

Tang, L.-M.; Chen, S.-T.; Cheng, S.-Y.; Lyu, R.-K.

The Role of Pulse-Wave Doppler Sonography in Quantifying 354 Internal Carotid Stenosis Fiori, L.; Parenti, G.

\section{Short Reports}

Acute Transverse Myelopathy and Cutaneous Vasculopathy in 359

Primary Sjogren's Syndrome

Lyu, R.-K.; Chen, S.-T.; Tang L -M.; Chen, T.-C.

A Pure Reversible Amnesic Syndrome following Tuberculous 363

Meningoencephalitis

Ceccaldi, M.; Belleville, S.; Royere, M.-L.; Poncet, M.

Book Reviews

Author Index Vol. 35,1995

369

Subject Index Vol. 35, 1995

Suppl. 1

Cerebral Ischemia. From Pharmacology to Modern Techniques and Clinical Implications International Symposium, Hangzhou, People's Republic of China,

May 14, 1994

Editors: J. Bogousslavsky, Lausanne; X.D. Wang, Beijing 
